\title{
Towards an approach to development as mission: the category of personhood as addressed by Amartya Sen?
}

\section{John Klaasen ${ }^{1}$}

\begin{abstract}
This paper is concerned with the role of personhood in development. I will be looking at the extent to which the influential model of development proposed by Amartya Sen does justice to the category of personhood. I will provide an overview of the work of Sen in the area of development and then provide some critical engagement. Drawing from the work of Sen this article provides some pointers or markers towards an approach to development as missionary role. Bosch's phrase "creative tension" provides a key principle for an approach to development.
\end{abstract}

Keywords: Sen, mission, personhood, agency

\section{Introduction}

This article is concerned with the role of personhood in development. Development has been an integral part of the ecumenical church and specifically the World Council of Churches. In 1961 the World Council of Churches established the Committee for Specialised Assistance to Social Projects to provide the mission boards with resources to assist with their ministry (Van der Bent 1981:69). Within the ecumenical movement development was a natural flow from the church's quest to play a relevant role in the changing environment post World War 2. The churches which had a long tradition of mission and projects amongst the disadvantaged played a major role to get the development debate on the church's agenda (Dickinson 1991:269). This became evident at the ecumenical conferences in Geneva (1966), Uppsala (1968) and Nairobi (1975).

I will be looking at the extent to which the influential model of development proposed by Amartya Sen does justice to the category of personhood. I am interested in the complex process through which people come to accept responsibility for addressing their situations. This interest is based on the intuition that personhood may well be crucial for any notion of development, precisely in impoverished contexts. Even when people are made aware of their opportunities and capabilities and where the obstacles thwarting development are removed, that would not necessarily translate into accepting responsibility. There is a gap (widely acknowledged in ethical theory) between

1 Dr John Klaasen is a lecturer in the Dept. of Theology and Religion, in the Faculty of Arts, at the University of the Western Cape. He can be contacted at jsklaasen@uwc.ac.za 
knowing what is right and doing what is right. It is here that reflection on the category of personhood may be crucial. The mission of the church which is embedded in the missio dei includes development of the individual and communities. The question that this article addressed is how the church can faithfully use personhood in light of development. The church has a tradition of engagement in the development debate especially post World War 2 . This article seeks to identify some of the weaknesses of the development debate and then make some suggestions how personhood can contribute to the development debate within the church.

\section{Sen and development}

Sen gives us glimpses of the use of personhood in his conceptualization of his approach. His approach, widely used in both secular and theological literature, can be summarised with reference to concepts such as freedom, agent, well-being, capabilities and functionings. I will give an overview of Sen's capability approach by explaining his use of these terms. Implicit in these terms is pointers to the use of personhood. Personhood is more explicit in the attempt by Sen to apply his capability approach to the individual and how she can effect personal and societal change. A few critical remarks will elicit the extent to which Sen makes use of personhood for development and his neglect thereof. These critical remarks are followed by an introduction to an approach in theological discourse that can make a contribution to effective mission in societies where the poverty level are increasing despite the efforts of institutions such as the Bretton Woods. The approach concerns the use of "axle" as a metaphor for mission and specifically that of the role of personhood in development. Such an approach to mission keep widely accepted antagonistic categories such as individual and community, church and the world in creative tension.

\section{Development as freedom.}

Development is not only about Gross National Product or individual income, but also about moral behaviour and to this effect ethics is an important partner of economics for development. This implies that individuals cannot only be viewed as commodities, but is instrumental in the process of development. When this is assumed then development is not only about the interpersonal valuation, but also about the intrinsic value of the individual. Therefore Sen claims that development is about the freedom the individual has to choose what is of value to her. He thus defines development "as a process of expanding the real freedoms that people enjoy" (1999:3). 
Freedom is central to the process of development for both the evaluative reason and the effectiveness reason. In other words freedom is a way of evaluating progress and this is done by asking the question, whether the freedoms of people are enhanced. The evaluative role refers to the success of a society based on the substantive freedom that the members enjoy. He explains this role by pointing out the differences between the capability approach and utility (happiness) or libertarian procedural liberty or real income approaches (Sen 1999:18). Sen includes classical utilitarianism of Bentham which are used by prominent economists such as Edgeworth, Marshall (1890), Pigou (1920), Ramsey and Robertson (1952). Utility is viewed as satisfaction or happiness. Also included in Sen's distinction of substantive freedom from utility is desire-fulfilment of modern utilitarianism. Hare (1981), Sidgwick (1874) and Gosling (1969) provide some of the clearest analysis of the pleasure and desire as modes of valuation (1999a:1-2).

With regard to the effectiveness reason, the question is whether the people are free agents. What is regarded as effective development refers to the choices that people can make about what they value. These choices pertains both to what effect the individual directly (nutrition and education) and indirectly (political and civil liberties) (Sen 1999:4-5).

It is worthwhile noting that the capabilities approach is not in contradiction with the traditional notion of economics, but it does depart from the notion that economic freedom is the $\mathrm{end}^{2}$.The traditional notion of economics is concerned with commodities and people, including how people make commodities, how they have control over it, what they do with it and what they get out of it (1999a:1). Sen points out that while people might have command over the characteristics or properties of the commodities, it does not guarantee the enhancement of the development of the person (1999:6) ${ }^{3}$. For example a person might own a car and possess the properties that go with owning the car. If the person cannot drive the car then we cannot judge the well-being of the person by the fact that she owns a car. Freedom then is the choice to, being able to drive, to choose whether a car will enhance that which the person value.

Another illustration is Aristotle's notion of wealth. It is not wealth, but freedom that enhances our life and foster development. Sen quotes Aristotle's words in the Nicomachean Ethics "wealth is evidently not the good we are

2 Here is similarities with the Aristotle's (flourishing) and Nussbaum's (quality of life) and Adam Smith's (necessities) approaches (24).See Nussbaum and Sen (eds) The quality of life 1993, "Nature, Function and Capability: Aristotle on Political distribution" Oxford studies in ancient philosophy, 1988 and Smith An inquiry into the nature and causes of the wealth of nations 1776 , Vol2, book5, chapter 2 .

3 For a more detailed discussion of characteristics and commodities see Sen, Poverty and Famines: An essay on entitlement and deprivation, Oxford university press, New York, 1981, pages 24-38. 
seeking; for it is merely useful and for the sake of something else" (translated by D.Ross (Oxford: Oxford University Press, revised edition, 1980), book1, section 5, p.7). In this sense development has to do with enhancing lives and freedoms. "Expanding the freedoms we have reason to value not only makes our lives richer and more unfettered, but also allows us to be fuller social persons, exercising our own volitions and interacting with-and influencing-the world in which we live" (1999:14-15). Freedom is about both the processes that foster freedom of actions and decisions and the opportunities that arise from personal and social circumstances. Unfreedoms can be a result of inadequate processes (violation of voting rights or political rights) or lack of opportunities (starvation, premature mortality). Freedom is connected to another important concept, well-being, which Sen uses in his notion of development.

Well-being is an important concept in the capability approach. Consistent with his critique of the overemphasis in the literature of the study of economics with commodities and personal wealth Sen claims that well-being cannot be effectively evaluated without considering at least five personal and social factors. The five circumstances are personal heterogeneities (different physical attributes like gender and abilities), environmental diversities (climate changes that can contribute to illnesses), variations in social climate (education, crime and violence), differences in relational perspectives (poor persons in rich communities requires more to be accepted and for fulfilment of self-respect) and distribution within the family (achievements depends on how the income is used and distributed amongst the members) (Sen 1999:70-72).

These personal and social factors can also not be limited to primary goods as in the case with Rawls's liberty theory. Primary goods are not an adequate valuation of well-being, because primary goods depend on how commodities are valuated between two or more persons. It also depends on the value that one give to a product compared to another. Capabilities have to do with actual real living or freedoms to be achieved. Well-being is directly related to the actual living of a person (Sen 1999:72-73).

Sen's approach is more about well-being and advantage than the narrow commodity approach. Well-being has to do with a person's achievements and advantage with the real opportunities compared with other possibilities. The use of opportunities must not be limited to its narrow sense of for example giving a disabled person the opportunity to attend a school that does not provide the necessary facilities for the person to function with real freedom.

Well-being is also closely associated with agency. Agency is different from well-being, though not completely independent, in respect to, "The former covers the person's achievements and opportunities in the context of his or her personal advantage, whereas the latter goes further and examines achievements and opportunities in terms of other objectives and values as 
well, possibly going well beyond the pursuit of one's own well-being" (Sen 1987:58-59). Agency is the person as doer of that which is beyond self-interest. An agent is actively involved in development of self, but also beyond the self. Whereas well-being deals with the self, agency can be fulfilled when the person contributed to the happiness of others.

Agency also has "effective power" to change circumstances and is therefore important for understanding the obligations of persons (Sen 2009:271).

Functioning is the fourth important part of the capability approach. Function is a means of valuing the well-being of a person. How well a person is, is reflected in the kind of life a person lives. Functioning takes in consideration the "doings" and "beings" of a person (1999a:19). It has to do with the actual activities that a person is able to do. It is not restricted to what the person knows of something but the capability to choose according to the value attached to the object. It is more about doing than knowing. In this sense it is about what is available to me and not necessarily what I make available to me.

Functioning moves beyond the possession of a commodity and has to do with what the person can do with the commodity. It answers the question, to what extend can the commodity be used by the person. "A functioning is an achievement of a person: what he or she manages to do or to be. It reflects, as it were, a part of the 'state' of that person. It has to be distinguished from the commodities which are used to achieve those functionings" (Sen 1999a:7). "The valued functionings may vary from such elementary ones as being adequately nourished and being free from avoidable disease, to very complex activities or personal states, such as being able to take part in the life of the community and having self-respect" (Sen 2008:199).

These four concepts as used in Sen's notion of development give us glimpses of the role of personhood in development. Freedom, well-being and to a lesser extend agency and functioning is about the nature of the person. A person is here referred to as an autonomous individual. This is implicit in the close connection between Sen's view of freedom and the right to choose what is of value. This explains the emphasis of the person to the external factors such as institutions, policies and communities that provide or neglect that which is necessary for freedom and well-being. The relationship is of an I-it nature. The person does not have an interdependent relationship with the external factors. These factors only serve to increase the choices. Increase in choices also does not necessarily translate into well-being. At this stage personhood has little role in development because of the overemphasis of the external factors that influences the person.

In the conceptualization of the individual Sen attempts to keep the tension between individual and society. Deneulin maintains that this tension, while possible on a theoretical level, is not sustainable for development practice. The reasons for this assertion is that there is a strong 
rational for the evaluative space to be extended beyond the self, because the individual depend on a collective framework for its authority, assessment development demands consideration beyond the individual and thirdly socio-historical contexts are important for individual agency (2008:107).

Whereas development in the conceptualisation stage has been largely discussed as the individual and her own development, I now move to the individual and the responsibility she has towards society through rational behaviour. To some extent Sen deals with Deneulin's critiques.

\section{Sen claims that the use of reason can promote better societies.}

In order to substantiate his claim about the use of reason for better societies he points out three arguments against reason as an evaluative framework and then presents counter arguments. Firstly considering the heterogeneity of values and preferences of people, a coherent framework for reasoned social assessment is impossible. To counter this claim Sen argues that information other than rules form specific circumstances. In other words more information is needed. Sensitivity to individual development is also needed. The second argument against reason, concerns our ability to have what we intend to have is always in tension with the more frequent and common "unintended consequences". Sen argues that unintended consequences should not be viewed as negative, but reasoned intended assessment brings better results. Adam Smith, Karl Menger and Friedrich Hayek are proponents of unintended consequences. Unintended causes may not be unpredictable. Thirdly can our modes of behaviour go beyond self-interest? Sen says justice and values can also move people (1999:249-250).

Sen furthermore claims that even in self-interest there is a concern beyond the individual. For example imagine you are confronted with a malnourished person. If you respond because the person makes you unhappy and by helping the person you will feel happy, that is sympathy. But if you respond because you are using more information than that which relates to your happiness, say for example justice, then your response is related to a sense of injustice. This is not sympathy, but commitment. In both responses there is a strong sense of the person self. Sympathy is an action that is about self-interest and commitment and although it has not directly to do with self-interest, it has to do with the self, because the commitment is one's own. Both responses are also rational choices (1999:270).

We must tread with caution because here it seems that sympathy and commitment is so far removed from each that the one is in opposition or contrary to the other. This is the case with Sen's treatment of the two concepts. It has a bearing on our conceptualisation of personhood. As 
Bronowski rightly puts it, "There is, as it were, the commitment at my end: the sense of devotion. And coupled with it there is what moves and directs my devotion, what my devotion finds: sympathy for you" (1965:97). There is a reciprocal process that combines the other with the self that make the self, complete. The other is also complete with the action of the self that is characterised by tolerance and trust. Tolerance for any possible difference and trust that the reception of the gift is with gratitude and graciousness.

Commitment to a humanitarian course for example does not guarantee success although it may satisfy self-interest. But if sympathy guides commitment then the outcome will be beyond self-gratification or self-interest that denies the selfhood of another. When sympathy is attached with commitment in this way then the self develops in relation with the other without selfishness but out of collegiality or the prosperity of common humanity.

Sen rightly argues that freedom plays an important role in the connection between the individual and social commitment. Perhaps the most explicit evidence of Sen's notion of personhood lies in the following provocative claim, "It is not so much a matter of having exact rules about how precisely we ought to behave, as of recognizing the relevance of our shared humanity in making the choices we face" (1999:283). Here we find a shift from the individualism that has been evident in the conceptualisation of the approach by Sen to the individual having commonality with other human beings. We also find here an attempt to counter the criticisms of Deneulin.

It is the responsibility of people to develop and change the world. An individual makes choices that will effect herself, but not without consequences for others and considerations of the institutions that create the freedoms that individuals value. Right and exact rules about how to behave is important, yet rules cannot replace our shared humanity. Here seems to be a tension between the individual and her interest and society and its needs. The tension has to do with the responsibility of the individual and that of the society.

This clearly raises the question of the use of reason as ontology for humanity. In other words how is reason used in order to understand personhood as creative tension between the individual and the collective? Reason is not an abstract activity because persons are not abstract atomic. Reason is both an independent and dependent variable, it is formed and informed. By implication the self is not in isolation, but is formed, informed and transformed through critical engaged reasoning (Klaasen 2012:113).

\section{Interdependence between freedom and responsibility}

Social responsibility does not replace individual responsibility. This approach by Sen is precisely about the individual taking responsibility for her development, but not without substantive freedoms. In other words 
responsibility can only be taken for development if social and environmental circumstances are taken in consideration together with personal circumstances. It is important here to guard against what is called the "nanny state", enforcing choices upon the individual through coercion. The idea is that individual responsibility should be supported by the state and other institutions (1999:284).

Again freedom also applies to our treatment of others, whether we want to develop with all good intentions or whether it is out of commitment. Freedom also influences our view of the other. How do we view those who are different than us or those who hold values that contradict our values? "Freedom is valued in a culture that wants to encourage dissent and to stimulate originality and independence. It belongs to a society which is open to change, and which esteems the agent of change, the individual, above its own peace of mind" (Bronowski 1965:101).

\section{Human capital and human capability}

Sen gives us another glimpse into his notion of humanity when he makes the difference between human capital and human capabilities. Although the two is not mutually exclusive human capital enhances production while human capabilities concentrate on the abilities of people to lead the lives they value and enhance their choices. Both have to do with the role of human beings, although they assess different achievements. While human capital assesses indirect value, how does this add to production, human capability assesses both the indirect and direct value (1999:293).

Sen uses Adam Smith's pioneering work Wealth of nations and The theory of moral sentiments that stresses the point that education and learning is primary to production possibilities. Instead of promoting nature, he is a strong proponent of nurture. Development has to do with formation over a period of time and is influenced by many varied factors. In this sense human beings are not the means to an end, for example greater markets or more investments, but are also the end. To view humanity as means reduce humanity to merely mean of production. In other words nothing more than a commodity (1999: 296).

Sen gives a broader view of what it means to be a human being than the approach of modern economics. A human being is much more than a commodity or the total economic income accumulated. To be human is to have well-being. Well-being refers to the possession of the characteristics of goods and the capability to apply it so that it is of value to the person. Functionings is a way of evaluating what the person is able to do with the commodity or goods. In other words how best are the goods applied for the enhancement of the life of the person? Coupled with this is the practical and mental involvement of the person in the valuing of the commodity or goods. 
This is referred to as agency. The person is not a passive recipient, but an active participant in the development process.

Sen views a human being in relation to what options the person has, what the person values, who the person is and what the person can become. "Sen presents in relation to his capabilities approach a very rich conception of the individual that gives not only a view of what a person is and does or could be and do but also of who the person is" (Teschl and Derobert 2008:126). Person is closely related to the individual with far less attention to humanity. The difference is that a person is exclusively an individual who is characterised by self-centredness and who has a relationship with institutions, non-living and other living beings as a selfish activity. The individual must be served in its quest for development.

\section{Points of critique}

The following points of critique can be raised in Sen's view of personhood. Firstly there is an overemphasis on individuality that limits the identity aspect of what it means to be human. To this effect Teschl and Derobert claim that "Sen presents a very rich view of the individual within the capability approach, without, however, ever linking it specifically to any concerns about identity" (2008:127). This assumption derives from the way Sen views freedom and the relationship between personal identity and social identity. Freedom is part of who the person is and development is determined by whether the freedom is expanded. Freedom is integral to how the individual view him/herself in relation to what she values for her life. In this sense freedom is also associated with personal identity because the person chooses that which is of value to her. Although there is a place for social identity, the person does not value the consequences of her actions or choices for the society more than the enhancement of her capabilities.

Secondly the overemphasis on individuality follows directly unto the nature of the relationship that the individual has with others and communities. The nature of the relationship is such that the others must serve the interest of the individual. This kind of relationship gives the individual independence from communities. Notwithstanding Sen's claim "of our shared humanity" (1999:283), the individual has a responsibility towards him or herself. Because of the distance between the individual and others, coupled with the evaluative and effectiveness aspects of freedom, a person will choose what is of value for herself. This turns persons into abstract individuals who have little regard for anything other than that which benefits its self-interest. Communities are there for the benefit of the individual and its value is determined not by its intrinsic value but by the role it plays in the broadening of the choices of the individual. 
A third point of critique relates to the narrow view of the way agency is appropriated by Sen. Sen give little power to institutions and social arrangements in the capacity of the person. The agent is actively involved in expanding freedoms in a one dimensional relationship between the individual and institutions. Although institutions play a role in constructing individual freedoms, like communities, its role is limited to the enhancing of the freedom of the individual. Sen claims that, "Not only do institutions contribute to our freedoms; their roles can be sensibly evaluated in the light of their contributions to our freedoms" (1999:142).

Agency needs to take institutions seriously in its quest to expand the capabilities that is of value to the individual. Institutions have a dual role. It has value in relation to the agent and it has intrinsic value. Deneulin introduces the notion of Paul Ricoeur, 'structures of living together' to clarify the seemingly contradiction. "Structures of living together can be defined as structures which belong to a particular historical community, which provide the conditions for individual lives to flourish, and which are irreducible to interpersonal relations and yet bound up with these" (2008:111).

When agency takes place within "structures of living" it does not surrender autonomy, but it does take seriously the interconnectedness of the different structures that impact the individual. Structures or institutions are a living organism that gives life to agency and enhances not only the capabilities, but also the freedom of the individual.

Sen's use of personhood does not address the role of personhood in taking responsibility for development beyond choosing what is available. Personhood should play a role before the availability of capabilities. It is a crucial sense of personhood that is lacking in Sen capability approach.

\section{Christian mission, personhood and development}

My assumption is that one of the crucial factors that enables a person to develop personal integrity and thus to accept responsibility is an understanding of what being a human being entails. The category of personhood helps to describe such an understanding of being human. This would include at least a notion of human distinctiveness, of being related to others, of human dignity, respect for the otherness of others and a sense of a common humanity (Ubuntu).

It is here that Christian theology and more specifically a Christian mission approach makes a significant contribution to development. From a perspective of mission, how do we understand personhood? A preliminary answer is that "freedom and community as axle" serves as a metaphor to conceptualise personhood. In both secular literature and theological literature "freedom and community" form an important pillar to come to terms with the notion(s) of personhood. 
Bosch uses this axle in two ways. Firstly, the two "freedom" and "community" form the two central parts of the axle in Paul's notion of the church in the context of his missionary activities. Bosch claims that the communities that Paul established through his missionary activities, is called ecclesia, "commonly used in the Septuagint as translation for the Hebrew kahal. In contemporary Greek, ecclesia normally referred to the town meeting of free male citizens of a city of Greek constitution" (1991:165). The following can be derived from this understanding of ecclesia. The freedom of the citizens is closely connected to their status as found in the community. In the two letters to the Corinthians this new identity is especially re-enforced when certain members tried to assert their individual freedom to do as each of them pleases (1991:166). Freedom is bound up in the relationships that one has with the fellow members of the community. Freedom cannot be isolated from membership of the community.

Freedom is not restricted to the ability to choose what is of value for the self. To put it differently freedom is not thwarted when choice is for the well-being of the self. Freedom is integrated with the person's relationship with other members of the community.

Secondly, the axle is also used in the way the church community (ecclesia) relates to the world. The ecclesia is unique, distinct, new, and different but not an enclave in its relationship with the world. Bosch affirms that, "In Paul's understanding, the church is 'the world in obedience to God', the 'redeemed...creation' (Kasemann 1969b:134). Its primary mission in the world is to be this new creation...Yet precisely this has an effect on the 'outsiders'. Through their conduct, believers attract outsiders or put them off (cf Lippert 1968:166f)" (1991:168).

The members of the community do not withdraw from other communities or do not put up barriers to prevent interaction, but they relate to other communities with a renewed humility and generous spirit to share their uniqueness and distinctiveness. "The church is that community of people who are involved in creating new relationships among themselves and in society at large and, in doing this, bearing witness to the lordship of Christ. He is no private or individual Lord but always, as Lord of the church, also Lord of the world" (Bosch 1991:169).

The ecclesia "is possessed by a vision of God and the created order as open and engaged in a life-process. Unity is not to be equated with the denial of difference or the reduction of them all to one, but speaks of the mutual intercommunion and interpenetration of elements of difference" (Greenwood 1994:88). Even the differences is a result of our relations and its significance is not to emphasise the independent, complete product, but to the person in formation, through relation with other selves (Klaasen 2013:189). 
When the world is seen, heard, spoken to and acted upon, it is experienced beyond the physical appearance. This kind of interaction "evokes mystery, compassion, reciprocity, and obligation. It is as we look into another person's eyes and gaze upon the face of another person that we see with the 'eyes of the heart' and stand in openness before her and his ineffable and inexhaustible mystery" (Medley 2002:177 quotes La Cugna ).

Personhood cannot be limited to the autonomous individual or collection of individuals that is bound together for the benefit of the individual or common causes. The former denies the creativity of relationships and the latter "reduces all members of human society to the status of disposable cogs in the machine of a corporate enterprise" (Greenwood 1994:89). Personhood on the other hand is about the creativity to create space for open, trustworthy and loving relations. Like an axle that binds two wheels, while the two wheels are independent, the one cannot turn without the other.

During the medieval period when the church was preoccupied with how humans differ from nature there was an awareness of the creative tension. This was a preoccupation that was necessary for the church's consistent guard against any teachings that were contrary to; "the two central doctrines of God as Triune (i.e., one divine nature possessed equally by three distinct Persons, distinguished only by their relations of origin to each other) and Christ as God-man (i.e., one divine Person possessing two distinct natures, one divine, one human) (Clarke 1994:211).

Clarke however claims that Thomas Aquinas and other medieval scholastics did develop a relational notion of the person. Clarke argues that Aquinas' notion of real being is about two sides of the same coin, one intrinsically active and the other self-communicating. A being is an active being that communicates about itself to others and by communicating is communicated to. In a sense being is about active self-communication. There are two reasons why persons pour forth natural activity: one because it is poor and drawing from others as much as its nature allows towards fulfilment and secondly because being is rich and naturally shares the richness with others (Clarke 1994: 214).

This explanation of being as activity is demonstrable of the relationality of persons that is inseparable from the substantiality. Clarke concludes that "Therefore, all being is, by its very nature as being, dyadic, with an "introverted," or in itself dimension, as substance, and an "extroverted", or toward-others dimension, as relational trough action... This dynamic polarity between substance and action-plus-relations was submerged and almost forgotten in the post-medieval period from Descartes on" (1994: 216-217). 
The Enlightenment scientific, technological and free individualism has found renewed criticism from theologians. The Christian tradition finds itself in a paradigm shift that questions the absolute autonomous individual as the most objective and highest form of being. Being is not equivalent to self-determination, but the extent to which one mirrors the likeness of God. The likeness of God here refers to Trinitarian ontology of relation amongst Father, Son and Holy Spirit (Klaasen 2013:88).

In Hebrew theology as in Ancient Israel humanity had an I-Thou relationship with God. This relationship referred to each person created "in the image of God". This means that people are bound together in an inescapable relationship of mutual growth. Martin Buber, Jewish scholar reminds us that the "I-Thou" relationship is a very demanding one and many times the "Thou" gets reduced to an "it" because of the intensity of the "I-Thou" relationship on humans. The "it" is easier because it reduces the person to an object that makes fewer or lesser demands on us. It reduces the time, energy, giving of self and effort. De Gruchy reminds that this can be dehumanizing abuse and manipulation of others (2006:43).

Personhood points beyond the individual and engages with others in a reciprocal relationship that seeks to development both the self and the other. The nature of personhood is such that taking responsibility for development is not an activity that is undertaken for selfish reasons. It is undertaken for the transformation of the self and the other. The other here is all those who are in need of transformation in order to reach their full potential in a mutually enriching process.

This is demonstrated in De Gruchy's notion of personhood. De Gruchy finds both a distinction and commonality in personhood. In describing a common humanity he makes the distinction between individual, persons and human. The individual is associated with post-Enlightenment and the emphasis on individual human rights against the monarchical, authoritarian and totalitarian forces. While such individualism is good for individual responsibility, the danger is that absolute individualism has been responsible for gross human rights violations and genocides in the last few decades (De Gruchy 2006:42-43).

Personal identity is more closely related to process. It is the construction of each person as unique persons from our birth into teens, middle age and old and finally death. The process is made up of particular and specific factors such as our gender, our bodies, sexuality and culture. Here, particularly the formulation of the Trinity is related to personal identity by the distinct, yet not isolated from each other. In other words personal is always interpersonal (2006:44).

Humaneness is about the sameness of humanity. The commonalities might be expressed differently, for example to love can be done differently by defend persons, yet love is common to all humans (De Gruchy 2006:46). 
These three individual, personal identity and being human is interrelated and through a process common humanity at birth right develops into human wellbeing. To this effect De Gruchy claims that, "If our common humanity is something given, everyone's birth right, becoming more truly human is shaped by choices and responses we make, in which we become more fully ourselves, more aware of our common humanity, and when we nurture the humanity of others. The wonder in all of this is that as people become more truly human, their different personalities are enhanced in terms of their own capacities-they become distinctly themselves yet more aware of their relationship to others" (2006:52)

\section{Conclusion}

Sen provides important glimpses into the role of personhood through the conceptualisation of the key concepts of his capability approach. The capability approach is a widely accepted one in secular and theological approaches to development. His emphasis on the capability of the individual to choose what the individual value for she does not adequately answer the question about the role of personhood in development. This is no weakness of Sen because he never claims to be doing so. However, in order to make choices for development implies an understanding of the self or the person and the intrinsic role that personhood plays in development. It is these implications of understanding the self or the person that both give us glimpses of the role of personhood and the imperative for a greater role of personhood in development if space is created for such a role.

This article has attempted to highlight Sen's use of personhood. I have also given some critique to foster greater critical engagement with the approach of Sen. Some of the critiques includes the overemphasis of the individual that limits identity. The one dimensional nature of the relationship between the individual and the other, including communities, leans towards sympathy and self - interest and not a commitment towards other social identity. The narrow view of the appropriation of agency excludes the role that structures and institutions play in the formation of personhood.

By using the metaphor of the axle to begin to conceptualise personhood one brings out some of the basic creative tensions that exist alongside each other. Bosch's use of the creative tension between the individual and community and the ecclesia and the world is a starting point for further development of the role of personhood in development. 


\section{Bibliography}

Andreassen, B.A., and Marks, S.P., (eds.), 2010, Development as a human right: Legal, political and economic dimensions (2nd edition), Intersentia, Oxford.

Basu, K., Pattanaik, P and Suzumura, K., (eds.), 1995, Choice, welfare and development: A festschrift in honour of Amartya K. Sen, Clarendon Press: Oxford.

Bosch, J.B., 1991, Transforming mission: Paradigm shifts in theology of mission, Orbis books, New York.

Bronowski, J., 1965, The identity of man, Heinemann Educational Books, London.

Clarke, W.N., 1994, Explorations in metaphysics: being, God, person, University of Notre Dame, Notre Dame, Indiana.

Comim, F., Qizilbash, M., and Alkire S., (eds.) 2008, The capability approach: Concepts, measures and applications, Cambridge university press, Cambridge.

Dickinson, R., 1991, 'Development', in N. Lossky, J.M. Bonino, J. Pobee, T. Stransky, G. Wainwright \& P. Webb (eds.), Dictionary of the ecumenical movement', WCC Publications, Geneva, pp. 268-274.

De Gruchy, J., 1995, Christianity and democracy, David Philip, Cape Town.

De Gruchy, J., 2006, Being human: confessions of a Christian humanist, SCM Press, London

Foster, J.E., and Sen, A., 2008, On economic inequality, Clarendon press, Oxford.

Greenwood, R., 1994, Transforming priesthood: A new theology of mission and ministry, SPCK, London.

Klaasen, J., 2008, 'The interplay between the Christian story and the Public story for moral formation under democratic rule' $\mathrm{PhD}$ thesis, Dept. of Systematic Theology, Stellenbosch University.

Klaasen, J. 2012. Open-ended narrative and moral formation. ACTA THEOLOGICA, Vol 32, No 2. December: 103-116.

Klaasen, J. 2013. The interplay between theology and development: How theology can be related to development in post-modern society. Missionalia, Vol 41 No 2, August: 182-194.

Medley, M.S., 2002, Imago Trinitatis: Toward a relational understanding of 
becoming human, University press of America, Maryland.

Sen, A., 1981, Poverty and famines: An essay on entitlement and deprivation, Oxford university press, New York.

Sen, A., 1982, Choice, welfare and measurement, Harvard university press, Cambridge.

Sen, A., 1987, On ethics and economics, Basil Blackwell, Oxford.

Sen, A., 1999, Development as freedom, Oxford university press, Oxford.

Sen, A., 1999a, Commodities and capabilities, Oxford University press, New Delhi.

Sen, A., 2009, The idea of justice, Penguin books Ltd, London.

Van Der Bent, A., 1991, Major studies and themes in the ecumenical movement, World Council of Churches, Geneva. 